\title{
ANALISIS PERBANDINGAN METODE MULTIDIMENSIONAL SCALING (MDS) DAN WEIGHTED MULTIDIMENSIONAL SCALING (WMDS)
}

\author{
Dea Pradita, Neva Satyahadewi, Hendra Perdana
}

\begin{abstract}
INTISARI
Analisis multivariat merupakan teknik statistik yang digunakan untuk menganalisis data terdiri dari banyak variabel yang saling berhubungan satu sama lain. Salah satu metode dalam analisis multivariat adalah metode Multidimensional Scaling (MDS). Metode MDS bertujuan untuk memberikan gambaran visual dari pola kedekatan yang berupa kesamaan atau jarak diantara beberapa objek. Penelitian ini menggunakan bentuk perluasan dari metode Multidimensional Scaling (MDS) yakni Metode Weighted Multidimensional Scaling (WMDS). Tidak banyak yang berbeda dari proses metode MDS biasa, hanya saja pembobotan yang dilakukan pada penelitian ini bertujuan untuk membuat nilai stress yang lebih baik. Nilai stress (Standarized Residual Sum of Square) merupakan alat ukur ketidak cocokan metode dengan data yang digunakan. Semakin kecil nilai stress maka dinilai semakin cocok. Pembobotan pada WMDS dilakukan menggunakan distribusi Uniform. Penelitian ini membandingkan metode MDS dan WMDS. Data yang digunakan adalah data primer tentang operator telepon seluler dari 90 orang mahasiswa FMIPA UNTAN. Hasil penelitian diperoleh perbedaan antara metode Multidimensional Scaling dan Weighted Multidimensional Scaling. Nilai stress pada metode MDS sebesar 0,092 (9,2\%) sedangkan pada metode WMDS sebesar 0,074 (7,4\%). Kedua metode tersebut menghasilkan nilai stress dengan kategori baik, hanya saja WMDS di nilai lebih baik karena mempunyai nilai yg lebih kecil dari MDS. Namun, pada peta persepsi yang terbentuk kedua metode menghasilkan peta persepsi yang serupa.
\end{abstract}

Kata Kunci: Multidimensional Scaling, Bobot, Analisis Multivariat

\section{PENDAHULUAN}

Analisis multivariat merupakan metode statistik yang dapat menganalisis data terhadap lebih dari dua variabel secara bersamaan. Banyak perusahaan yang menggunakan analisis multivariat ini untuk mengetahui seperti apa penilaian produknya di mata para konsumen. Teknik analisis ini dirancang sebagai bentuk komunikasi pemasaran sebuah perusahaan kepada konsumen untuk menentukan posisi yang akan ditepati oleh produk tersebut, yang biasa disebut dengan istilah product positioning. Analisis multivariat terbagi menjadi dua kategori metode, yaitu metode dependensi dan interdepedensi. Metode dependensi terdiri atas beberapa teknik analisis, yaitu regresi berganda, analisis diskriminan, korelasi kanonikal dan Manova. Metode interdependensi terdiri atas beberapa teknik analisis, yaitu analisis faktor, analisis kluster dan multidimensional scaling [1].

Multidimensional Scaling (MDS) adalah suatu teknik yang digunakan untuk mencari hubungan antar data secara spasial [2]. Hubungan pada analisis MDS membentuk sebuah grafik (map) untuk menggambarkan posisi sebuah objek dengan objek lain berdasarkan kemiripan (similarity) objekobjek tersebut [3]. Pada penelitian ini dilakukan analisis perluasan dari analisis $M D S$ yakni WMDS.

Perhitungan metode $M D S$ dilakukan dengan berbagai macam tahapan. Tahapan pertama adalah pengujian validitas dan reliabilitas pada data kuesioner yang digunakan. Setelah data dinyatakan valid dan reliabel langkah perhitungan dilanjutkan dengan menghitung elemen dari matriks jarak euclidean. Namun pada proses perhitungan WMDS dilakukan pemberian bobot pada jarak euclidean tersebut. Pembobotan pada penelitian ini menggunakan distribusi Uniform. Perbedaan antara kedua metode hanya terletak pada pemberian bobot untuk mendapat hasil yang lebih baik [4]. Tahapan berikutnya dilakukan proses yang sama antar kedua metode. Setelah mendapatkan matriks jarak euclidean, proses 
dilanjutkan dengan mencari nilai eigen dan vektor eigen. Nilai eigen dan vektor eigen yang telah didapat digunakan untuk membentuk peta persepsi. Proses terakhir dari kedua metode ini adalah dengan mencari stress value. Stress value merupakan alat untuk menilai atau menentukan goodness of fit pada metode kedua metode yang digunakan.

Data yang digunakan dalam penelitian ini berupa data primer tentang penggunaan operator telepon seluler yang terbagi dari tiga jenis produk. Ukuran data yang digunakan adalah sebanyak 90 data dan terdiri dari 14 variabel. Data tersebut diolah dengan software Microsoft Excel, SPSS, dan $R$.

\section{ANALISIS MULTIVARIAT}

Analisis multivariat digunakan karena pada kenyataannya masalah yang terjadi tidak dapat diselesaikan dengan hanya menghubungkan dua atau lebih variabel. Contoh penerapan analisis multivariat yakni pengaruh variabel kualitas produk, harga, promosi dan distribusi terhadap keputusan pembelian produk. Secara umum analisis multivariat diklasifikasi menjadi dua, yaitu analisis dependensi dan analisis interdependensi. Analisis dependensi berfungsi untuk menerangkan atau memprediksi variabel dependen dengan menggunakan dua atau lebih variabel independen. Sedangkan analisis interpedensi berfungsi untuk memberikan makna terhadap seperangkat variabel atau membuat kelompok secara bersama-sama tanpa melihat variabel tersebut dependen atau independen. [1]

\section{PETA PERSEPSI}

Peta persepsi atau perceptual map adalah sebuah bentuk representasi visual dari gambaran persepsi responden terhadap beberapa objek yang terdiri dari dua atau lebih dimensi. Setiap objek tersebut akan memiliki posisi spasial pada peta yang telah dideskripsikan sesuai kesamaan (similarity) dan preferensi (preference) ke objek lainnya. Pembentukan peta persepsi tersebut bertujuan untuk melihat perbedaan produk dan jasa yang dilihat konsumen dalam persaingan merek pada satu atau beberapa karakteristik yang relevan. Selain itu, peta persepsi juga berguna untuk memilih dan memutuskan bagaimana menentukan sasaran untuk langkah penjualan selanjutnya. Pemetaan persepsi menunjukkan posisi barang dan jasa yang dipilih konsumen sesuai dengan yang dirasakan. Tiap-tiap pilihan menempati tempat khusus, pilihan yang memiliki kesamaan akan saling berdekatan, sedangkan yang memiliki banyak perbedaan akan saling berjauhan [6].

\section{STRESS VALUE}

Stress Value (Standarized Residual Sum of Square) merupakan alat ukur untuk ketidakcocokan metode yang digunakan untuk keadaan sebenarnya. Semakin tinggi Stress value yang didapat maka semakin tidak cocok. Adapun rumus dari stress value adalah sebagai berikut:

$$
S=\left(\frac{\sum_{i, j}^{n}\left(d_{i j}-\hat{D}_{i j}\right)^{2}}{\sum_{i, j}^{n} d_{i j}^{2}}\right)
$$

Dimana

$$
\begin{aligned}
& d_{i j}=\text { Jarak euclidean individu baris ke-i terhadap individu kolom ke-j } \\
& \hat{D}_{i j}=\text { Selisih dari titik koordinat yang terbentuk }
\end{aligned}
$$

Stress value yang telah didapat dapat digunakan untuk menilai atau menentukan goodness of fit pada metode Multidimensional Scaling. Hair memberikan tinjauan dalam interpretasi stress value mengenai goodness of fit dari solusi yang ditunjukkan pada Tabel 1 berikut [2]: 
Tabel 1 Kriteria Stress Value

\begin{tabular}{cc}
\hline Stress Value $\mathbf{( \% )}$ & Kesesuaian \\
\hline $0-2,5$ & Sempurna \\
$2,5-5$ & Sangat Baik \\
$5-10$ & Baik \\
$10-20$ & Cukup Baik \\
$>20$ & Buruk \\
\hline
\end{tabular}

\section{UJI VALIDITAS DAN RELIABILITAS}

Uji validitas adalah suatu langkah pengujian yang dilakukan terhadap isi (content) dari suatu instrumen, dengan tujuan untuk mengukur ketepatan instrumen yang digunakan dalam suatu penelitian [7]. Kuesioner dikatakan valid jika pertanyaan pada kuesioner mampu untuk mengungkapkan suatu yang akan diukur oleh kuesioner tersebut [8]. Nilai variabel dikatakan valid jika nilai korelasi $\left(r_{\text {hitung }}\right)$ lebih besar dari nilai $r_{\text {tabel }}$. Perhitungan nilai $r_{\text {tabel }}$ dapat menggunakan rumus interpolasi.

Uji reliabilitas menunjuk pada suatu pengertian bahwa instrumen yang digunakan dalam penelitian untuk memperoleh informasi yang digunakan dapat dipercayai dan mampu mengungkapkan informasi yang sebenarnya di lapangan [9]. Suatu kuesioner dikatakan reliabel atau handal jika jawaban seseorang terhadap pernyataan konsisten atau stabil dari waktu ke waktu [8]. Penelitian dianggap dapat diandalkan bila memberikan hasil yang konsisten untuk pengukuran yang sama. Tinggi rendahnya reliabilitas secara empiris ditunjukkan oleh suatu angka yang disebut nilai koefisien reliabilitas. Kesepakatan secara umum suatu data dapat dikatakan reliabel jika nilai koefisien reabilitasnya lebih besar dari 0,60 .

\section{TAHAPAN PENGERJAAN MULTIDIMENSIONAL SCALING (MDS)}

Tahapan pada metode Multidimensional Scaling sebagai berikut:

1. Menentukan jarak euclidean

$$
\delta_{i j}=\sqrt{\sum_{h=1}^{n}\left(x_{i h}-x_{j h}\right)^{2}}
$$

2. Menghitung matriks $A$

$$
a_{i j}=-\frac{1}{2} \delta_{i j}^{2}
$$

3. Mencari matriks $B$

$$
b_{i j}=a_{i j}-\bar{a}_{i .}-\bar{a}_{. j}+\bar{a}_{.}
$$

dimana:

$$
\bar{a}_{i .}=\sum_{j=1}^{n} \frac{a_{i j}}{n} ; \bar{a}_{. j}=\sum_{i=1}^{n} \frac{a_{i j}}{n} ; \bar{a}_{. .}=\sum_{j=1}^{n} \frac{a_{i j}}{n^{2}}
$$

4. Mencari nilai eigen dan vektor eigen dari matriks $B$

$$
\begin{aligned}
\operatorname{det}(\boldsymbol{B}-\lambda \boldsymbol{I}) & =0 \\
\boldsymbol{B} \boldsymbol{x} & =\lambda \boldsymbol{x}
\end{aligned}
$$

5. Mencari titik koordinat dan stress value

$$
\begin{aligned}
& Z=\left(\sqrt{\lambda_{1}} v_{1}, \sqrt{\lambda_{2}} v_{2}\right) \\
& S=\left(\frac{\sum_{i, j}^{n}\left(\delta_{i j}-\widehat{D}_{i j}\right)^{2}}{\sum_{i, j}^{n} \delta_{i j}^{2}}\right)
\end{aligned}
$$




\section{TAHAPAN PEMBOBOTAN}

Pada metode $M D S$ telah diketahui bahwa $\delta_{i j}$ menjelaskan nilai dari elemen matriks jarak euclidean. Pada metode WMDS jarak euclidean dijelaskan dengan $d_{i j}=\delta_{i j} w$ untuk mengidentifikasi bobot jarak euclidean berdasarkan bobot yang tidak diketahui di vektor $w$ lalu menentukan bobot yang paling sesuai dengan ketidaksamaan yang diamati. Perhitungan untuk bobot dari data matriks asli menggunakan distribusi uniform. Distribusi uniform dengan persamaan yang digunakan, sebagai berikut:

$$
w_{i j}=\frac{\sum_{i=1}^{n} \delta_{i j}}{\sum_{j=1}^{n}\left(\sum_{i=1}^{n} \delta_{i j}\right)}
$$

Dimana:

$w_{i j} \quad$ : bobot dengan distribusi uniform

$\delta_{i j} \quad:$ Jarak euclidean individu baris ke-i terhadap individu kolom ke-j dengan metode Multidimensional Scaling (MDS)

\section{STUDI KASUS}

Pengumpulan data dilakukan secara langsung yakni dengan metode wawancara menggunakan kuesioner kepada mahasiswa FMIPA UNTAN. Jumlah sampel yang diambil sebanyak 90 responden. Prosedur pengambilan sampel dengan pendekatan Maholta bahwa syarat jumlah sampel yang diambil untuk penelitian harus memiliki kriteria tertentu minimal 4 atau 5 kali jumlah variabel atau atribut yang ditetapkan. Maka jumlah sampel yang diambil berdasarkan pertimbangan diatas dengan jumlah atribut sebanyak 14 maka sampel yang diambil yakni sebanyak 90 responden. Sedangkan untuk teknik pengambilan sampel digunakan accidental sampling. Accidental sampling adalah teknik penentuan sampel berdasarkan kebetulan bertemu dengan peneliti dapat digunakan sebagai sampel, bila dipandang orang yang kebetulan ditemui cocok sebagai sumber data [10].

Analisis data pada penelitian ini menggunakan metode $M D S$ dan juga menggunakan metode WMDS dengan pembobotan distribusi Uniform. Analisis data dilakukan dengan bantuan software SPSS dan R. Kedua software tersebut dipilih karena cukup mudah, tampilannya lebih sederhana dan cukup popular digunakan oleh peneliti lain untuk menangani metode ini. Responden diminta untuk memberikan penilaian sangat tidak setuju (STS), tidak setuju (TS), Setuju (S), ataukah Sangat Setuju (SS) terhadap masing masing variabel, sebagai berikut:

1. Tarif dalam menelpon atau mengirim pesan singkat terjangkau $\left(x_{1}\right)$

2. Suara terdengar jernih saat menelpon $\left(x_{2}\right)$

3. Jarang terjadi gangguan sinyal $\left(x_{3}\right)$

4. Sinyal kuat saat berada di daerah perdesaan $\quad\left(x_{4}\right)$

5. Layanan untuk internet memiliki kualitas yang memuaskan $\left(x_{5}\right)$

6. Tarif kouta internet terjangkau $\left(x_{6}\right)$

7. Tidak terjadi kesulitan dalam menemukan informasi $\left(x_{7}\right)$

8. Bonus yang ditawarkan banyak $\left(x_{8}\right)$

9. Masa aktif kartu panjang $\left(x_{9}\right)$

10. Isi ulang voucher dan elektrik mudah ditemukan $\quad\left(x_{10}\right)$

11. Iklan produk menarik, kreatif, serta mudah dicerna $\left(x_{11}\right)$

12. Kesesuaian iklan dengan fakta terhadap layanan produk $\quad\left(x_{12}\right)$ 
13. Pemilihan kartu dipengaruhi oleh citra perusahaan $\quad\left(x_{13}\right)$

14. Pemilihan kartu dipengaruhi oleh lingkungan sehari-hari $\quad\left(x_{14}\right)$

Setelah data diinput, langkah pertama pengerjaan ialah dengan pengujian validitas dan realibilitas. Hasil didapat adalah terdapat empat variabel yang tidak valid seperti pada Tabel 2. Sehingga dilakukan pengujian validitas dan reliabilitas kembali dengan mengeluarkan satu persatu variabel yang tidak valid.

Tabel 2 Tabel variabel yang tidak valid

\begin{tabular}{ccrl}
\hline Variabel & r-hitung & r-tabel & Keterangan \\
\hline$x_{4}$ & 0,130 & 0,143 & Tidak Valid \\
$x_{7}$ & 0,113 & 0,143 & Tidak Valid \\
$x_{9}$ & 0,049 & 0,143 & Tidak Valid \\
$x_{13}$ & $-0,237$ & 0,143 & Tidak Valid \\
\hline
\end{tabular}

Setelah dilakukan pengujian ulang dengan bantuan software SPSS didapat hasil uji reliabilitas seperti Tabel 3, yaitu:

Tabel 3 Uji Reliabilitas

\begin{tabular}{|c|c|}
\hline $\begin{array}{c}\text { Cronbach's } \\
\text { Alpha }\end{array}$ & Nof Items \\
\hline, 617 & 10 \\
\hline
\end{tabular}

Berdasarkan output yang didapat, dalam pengujian reliabilitas diperoleh nilai Chonbach's Alpha sebesar 0,617 $(>0,60)$ dan semua variabel telah valid. Sehingga dapat dikatakan bahwa data tersebut telah bisa dipercaya dan dilanjutkan ke analisis selanjutnya. Sehingga penelitian ini dilanjutkan dengan menggunakan 10 variabel yang telah valid dan reliabel, yakni:

1. Tarif dalam menelpon atau mengirim pesan singkat terjangkau $\left(x_{1}\right)$

2. Suara terdengar jernih saat menelpon $\left(x_{2}\right)$

3. Jarang terjadi gangguan sinyal $\left(x_{3}\right)$

4. Layanan untuk internet memiliki kualitas yang memuaskan $\quad\left(x_{5}\right)$

5. Tarif kouta internet terjangkau $\left(x_{6}\right)$

6. Bonus yang ditawarkan banyak $\quad\left(x_{8}\right)$

7. Isi ulang voucher dan elektrik mudah ditemukan $\left(x_{10}\right)$

8. Iklan produk menarik, kreatif, serta mudah dicerna $\quad\left(x_{11}\right)$

9. Kesesuaian iklan dengan fakta terhadap layanan produk $\quad\left(x_{12}\right)$

10. Pemilihan kartu dipengaruhi oleh lingkungan sehari-hari $\quad\left(x_{14}\right)$

\section{PEMBOBOTAN}

Perhitungan bobot dilakukan dengan distribusi uniform yang telah dijelaskan sebelumnya. Berdasarkan hasil pembobotan pada Tabel 4 dijelaskan bahwa variabel yang paling besar adalah variabel $x_{3}$ (jarang terjadi gangguan sinyal). Bagi responden hal terpenting dalam memilih kartu provider ditentukan berdasarkan sinyal yang baik. Sinyal tersebut dapat digunakan pengguna untuk berkomunikasi kapanpun dan dimanapun. Selanjutnya, variabel yang paling kecil adalah variabel $x_{2}$ (suara terdengar jernih saat menelpon). Hal ini berarti variabel suara terdengar jernih tidak terlalu penting bagi responden. Perhitungan bobot dapat dilihat pada Tabel 4 sebagai berikut: 
Tabel 4 Tabel pembobotan dengan menggunakan distribusi uniform

\begin{tabular}{ccccc}
\hline$x_{1}$ & $x_{2}$ & $x_{3}$ & $x_{5}$ & $x_{6}$ \\
\hline 0,09754 & 0,09189 & 0,10695 & 0,09463 & 0,10626 \\
\hline$x_{\mathbf{8}}$ & $x_{\mathbf{1 0}}$ & $\boldsymbol{x}_{\mathbf{1 1}}$ & $\boldsymbol{x}_{\mathbf{1 2}}$ & $\boldsymbol{x}_{\mathbf{1 4}}$ \\
\hline 0,09776 & 0,10649 & 0,09690 & 0,09668 & 0,10486 \\
\hline
\end{tabular}

\section{PERBANDINGAN METODE MULTIDIMENSIONAL SCALING (MDS) DAN METODE WEIGHTED MULTIDIMENSIONAL SCALING (WMDS)}

Setelah dilakukan pembobotan untuk metode WMDS, proses perhitungan dilanjutkan dengan bantuan software R. Peta persepsi yang terbentuk diperoleh dari titik koordinat pada dimensi 1 (koordinat $X$ ) dan titik koordinat pada dimensi 2 (koordinat $Y$ ). Maka didapat peta persepsi dengan kedua metode pada Gambar 1 dan 2 adalah sebagai berikut:

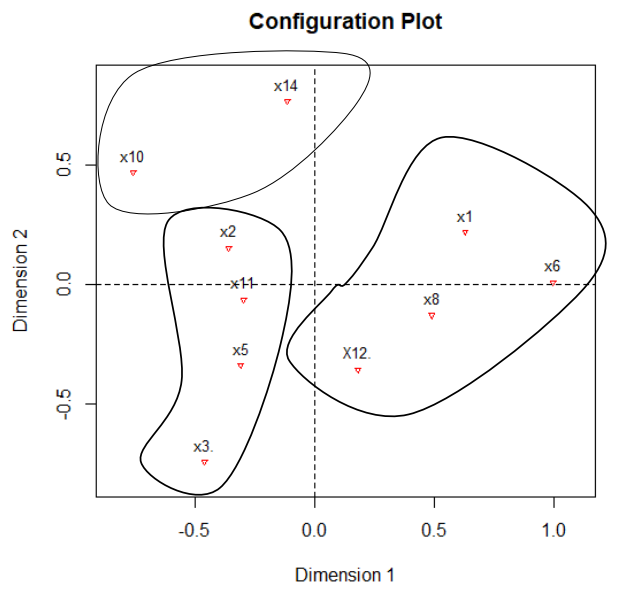

Gambar 1 Peta persepsi metode Multidimensional Scaling (MDS)

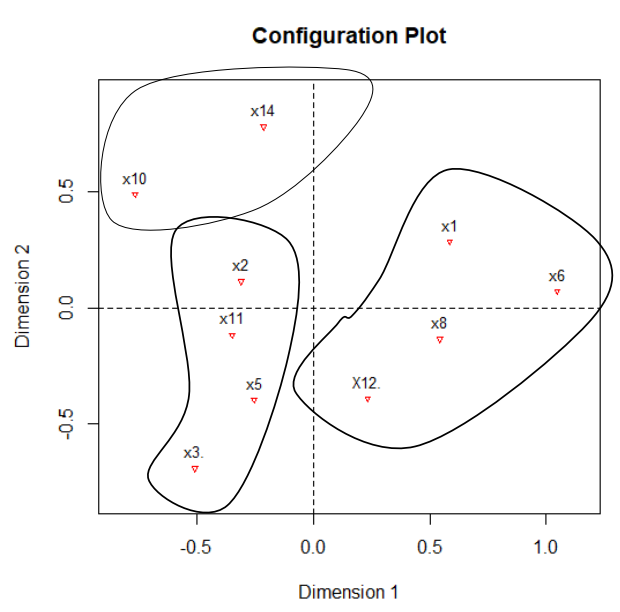

Gambar 2 Peta persepsi metode Weighted Multidimensional Scaling (WMDS)

Pada Gambar 1 dan Gambar 2 dapat disimpulkan bahwa kedua metode mempunyai hasil yang hampir sama pada peta persepsi yakni terdapat 3 kelompok yang memiliki kemiripan pada persepsi responden. Pada kelompok 1 terdapat variabel $x_{10}$ dan $x_{14}$ yakni variabel isi ulang kartu mudah ditemukan dan variabel pemilihan kartu dipengaruhi oleh lingkungan. Responden menilai bahwa ketiga produk operator telepon seluler ini setuju dengan pernyataan dari variabel variabel tersebut.

Pada kelompok 2 terdapat variabel $x_{2}, x_{3}, x_{5}$ dan $x_{11}$ yang memiliki kemiripan penilaian oleh responden. Hal ini dibenarkan karena sebagian besar responden menilai setuju untuk variabel suara jernih pada ketiga operator seluler. Begitu pula halnya dengan variabel layanan internet memuaskan dan juga variabel iklan dari ketiga operator seluler dinilai menarik oleh responden. Namun, pada variabel jarang terjadi gangguan sinyal responden berpendapat berbeda dengan produk 2. Sebagian besar responden menilai bahwa produk 2 sering terjadi gangguan sinyal.

Pada kelompok 3 terdapat variabel $x_{1}, x_{6}, x_{8}$ dan $x_{12}$ yang memiliki kemiripan penilaian oleh responden, hal ini berarti ketiga produk operator seluler saling bersaing dalam memajukan kualitasnya. Pada variabel tarif telepon dan kouta internet responden menilai produk 2 dan produk 3 memiliki tarif yang lebih terjangkau dibanding produk 1. Begitu halnya yang terjadi pada variabel bonus banyak responden menilai produk 2 dan produk 3 memiliki bonus yang lebih banyak dibanding produk 1 . Tetapi untuk variabel kesesuaian iklan dengan fakta responden menilai produk 3 memiliki iklan yang tidak sesuai dengan fakta. 
Namun untuk stress value pada Weighted Multidimensional Scaling lebih baik dibandingkan dengan metode Multidimensional Scaling. Hal ini artinya, dengan menggunakan metode Weighted Multidimensional Scaling peneliti menemukan kecocokan antar metode dan solusi yang lebih baik dibanding metode Multidimensional Scaling. Selain itu, peta persepsi yang terbentuk dengan metode Weighted Multidimensional Scaling mempunyai bentuk yang serupa bila dengan metode Multidimensional Scaling. Meskipun terdapat sedikit perbedaan, namun hal tersebut tidak terlihat nyata. Perbandingan stress value dapat dilihat pada Tabel 5 adalah sebagai berikut:

Tabel 5 Perbandingan stress value

\begin{tabular}{lc}
\hline Multidimensional Scaling & 0,092 \\
Weighted Multidimensional Scaling & 0,074 \\
\hline
\end{tabular}

\section{KESIMPULAN}

Berdasarkan hasil analisis penerapan metode Multidimensional Scalling (MDS) dan Weighted Multidimensional Scalling (WMDS) terhadap analisis persepsi mahasiswa FMIPA UNTAN terhadap operator telepon seluler diperoleh kesimpulan bahwa:

1. Studi kasus pada kedua metode tersebut menghasilkan tiga kelompok karakteristik yang sama dalam kemiripan antara ketiga operator telepon seluler. Kelompok 1 terdapat variabel $x_{10}$ ( isi ulang kartu mudah ditemukan) dan $x_{14}$ (pemilihan kartu dipengaruhi oleh lingkungan). Kelompok 2 terdapat variabel $x_{2}$ (suara terdengar jernih), $x_{3}$ (Jarang terjadi gangguan sinyal), $x_{5}$ (layanan untuk internet memiliki kualitas yang memuaskan) dan $x_{11}$ (iklan operator seluler menarik, kreatif, serta mudah dicerna). Pada kelompok 3 terdapat variabel $x_{1}$ (tarif telpon dan mengirim pesan singkat terjangkau), $x_{6}$ (tarif kouta internet terjangkau), $x_{8}$ (bonus yang ditawarkan banyak) dan $x_{12}$ (kesesuaian iklan dengan fakta terhadap layanan).

2. Kedua metode tersebut menghasilkan stress value yang berbeda. Pada Multidimensional Scaling stress value yang terbentuk adalah sebesar 0,092. Sedangkan pada Weighted Multidimensional Scaling yang terbentuk adalah sebesar 0,074. Kesimpulan yang didapat bahwa metode Weighted Multidimensional Scaling dinilai lebih baik karena memiliki stress value yang lebih kecil dibandingkan metode Multidimensional Scaling.

\section{DAFTAR PUSTAKA}

[1] Wijaya T, Budiman S. Analisis Multivariat untuk Penelitian Manajemen. Yogyakarta: Pohon Cahaya; 2016.

[2] Eka S, Setiawan D, Mubarok R. Analisis Multi Dimensional Scaling pada Kabupaten Papua Berdasarkan Faktor-Faktor yang Memperngaruhi Indeks Pembangunan Manusia (IPM) Tahun 2013, Surabaya: Institut Teknologi Sepuluh Nopember; 2017.

[3] Herman T. Penerapan Model Multidimensional Scaling Dalam Pemetaan Brand Positioning Internet Service Provider. Journal The Winners. 2009; (11):81-93.

[4] Greenacre M. Weight Metric Multidimensional Scaling. Barcelona: Universitas Pompeu Fabra; 2003.

[5] Rizkiyanti dan Wulandari. Analisis Regresi Multivariat Berdasarkan Faktor-Faktor Yang Mempengaruhi Derajat Kesehatan Di Provinsi Jawa Timur. Surabaya: Institusi Teknologi Sepuluh Nopember; 2010.

[6] Anastasia N. Peta Persepsi Konsumen Terhadap Atribut Rumah Tangga Di Surabaya, Jurnal Manajemen dan Kewirausahaan. 2013; (15):141-152.

[7] Sugiyono. Di dalam: Mulyatiningsih, E. (ed). Statistika untuk Penelitian. Bandung: CV Alfabeta; 2006. 
[8] Ghozali I. Aplikasi Analisis Multivariate dengan program SPSS. Semarang: Badan Penerbit Universitas Diponegoro; 2009.

[9] Sitinjak, Sugiarto. Lisrel. Yogyakarta: Graha Ilmu; 2006.

[10] Purwadi B. Riset Pemasaran. Jakarta:Grasindo; 2000.

DEA PRADITA $\quad$ : Jurusan Matematika FMIPA UNTAN, Pontianak deaprdt@gmail.com

NEVA SATYAHADEWI : Jurusan Matematika FMIPA UNTAN, Pontianak neva.satya@math.untan.ac.id

HENDRA PERDANA : Jurusan Matematika FMIPA UNTAN, Pontianak hendra.perdana@math.untan.ac.id 